\title{
Management of red rust thrips, Chaetanophothrips signipennis (Bagnall) in banana
}

\author{
K. D. Bisane ${ }^{1 *}$, S. P. Saxena ${ }^{2}$ and B. M. Naik ${ }^{1}$ \\ ${ }^{1}$ Fruit Research Station, ICAR-AICRP on Fruits (Banana, Sapota, Papaya), Navsari Agricultural University, \\ Gandevi - 396360 (Gujarat), INDIA \\ ${ }^{2}$ College of Agriculture, Navsari Agricultural University, Waghai - 394730 (Gujarat), INDIA \\ *Corresponding author. E-mail: kdbisane@yahoo.co.in
}

Received: June 4, 2016; Revised received: October 24, 2016; Accepted: January 18, 2017

\begin{abstract}
The commercial value of banana is mainly affected by red rust thrips, Chaetanophothrips signipennis (Bagnall) during fruiting phase at maturity. In this context, the trial was framed at F.R.S., N.A.U., Gandevi under ICAR-AICRP (Fruits) programme. The three years data on efficacy of bio-rational pesticides for management of red rust thrips revealed that bud injection of imidacloprid $(0.3 \mathrm{ml} / 500 \mathrm{ml}$ water $) @ 1 \mathrm{ml} / \mathrm{bud}$ exhibited lowest unblemished fruits up to $8.37 \%$ over conventional spraying $(20.72 \%)$ and bunch sleeving method $(42.83 \%)$. The comparable results on fruit damage (14.83\%) was observed with bud injection of azadirachtin (1\%) (5 ml/l water) @ $2 \mathrm{ml} /$ bud over conventional spray. The merit of technology furnished higher no. of unblemished fruits $(<10 \%)$ and original peel superficial appearance remains impassive under bud injection technique with higher benefit cost ratio with very low dose of pesticide provide financial profit to growers and traders. Besides, imidacloprid residue was not detected in harvested fruits and there is no other technology available to remove this malady of banana
\end{abstract}

Keywords: Banana, Chaetanophothrips signipennis (Bagnall), Red rust thrips

\section{INTRODUCTION}

Banana is one of cheapest staple food for the millions of the people, which fulfill the nutritional requirements of human diet. In present situation, the fruit feature is mainly concerned to offer high market price with low plant protection expenditure. Under such circumstances, banana plant parts are disfigured by different insect pest, mite and nematodes, which limit the quantitative and qualitative aspect of banana and plantains. About 19 insect pests were found damaging the banana in India and cause economic loss (Padmanaban and Mustaffa, 2010). Among them, red rust thrips, Chaetanophothrips signipennis (Bagnall) (Thysanoptera: Thripidae) affect the superficial appearance and significance of the fruits peel surface, which loss its importance and fetch low sale price at wholesale and retail market. There is no loss in fruit yield of the banana due to rust thrips damage, but it mainly concern to fruit quality and which fix on the market grade and price.

This pest has a diverse distribution in Asia particularly in India, Indonesia, Java, Philippines and Sri Lanka. In the Western Hemisphere, it has been reported in Brazil, Costa Rica, French West Indies, Honduras, Mexico, Panama, Puerto Rico and Trinidad and Tobago. In the USA, it is present in Hawaii and Florida. In Oceania, the banana thrips is recorded in New South Wales and Queensland (Australia), Fiji and Papua New Guinea (Schotman, 1989). Under South Gujarat banana farming region, more than $50 \%$ fruits were found affected by rust thrips infestation and diminish market grade of fruits under unprotected condition (Anonymous, 2012). Similarly in nearer banana growing area of Jalgaon (Maharashtra), the abundance of red rust thrips infestation appeared June onwards to the extent of 14 to $29 \%$ from August to November during 2009-11 (Anonymous, 2011), which reached up to 16 to $35 \%$ between July to December during 2011-12 (Anonymous, 2013) and 16 to $34 \%$ between August to December during 2013-14 at fruiting stage (Anonymous, 2014). The primary host of rust thrips are banana, anthurium and dracaena although it also infest immature fruits of orange, mandarin, tomatoes, and green peas (Hara et al., 2002 ${ }^{b}$ ). Similarly, feeding has been recorded on citrus and tomato and a number of weed species (Simmonds, 1959). In Florida, it is foliage feeding thrips on wide range of foliage plants, while damage banana in Central America (Denmark and Osborne, 1985). According to Hara et al. $\left(2002^{\mathrm{a}}\right)$, the banana rust thrips is similar in appearance to two other introduced Chaetanaphothrips species, the anthurium thrips, C. orchidii (Moulton) and C. leeuweni (Karny), which also share the same hosts, including banana, ti, and anthurium. Sakimura (1975) differentiated banana rust thrips from the other two species by clear differences in body features on the basis of the presence in females of body hairs and glands. 
In India, red rust thrips, $C$. signipennis is becoming economically important pest in many banana growing belts of country specially Gujarat, Maharashtra and Tamil Nadu which limit the marketability of product, although quality remain infected in term of taste and nutrition. Red rust thrips causes infestation on a few plant species and banana plants are the only sources of infestation in the plantation. In respect to its life cycle, female laid eggs in plant tissues and newly hatched yellow nymphs feed for a few days. The mature nymphs migrate off the host into the soil and undergo pupation. The entire biology is completed in approx. 28 days (Hara et al., 2002 ${ }^{\mathrm{b}}$ ).

In banana, red thrips conceal inside the flower bud, conventional spraying by insecticides during fruiting stage is uneconomical and also harmful to natural enemies and the residue may cause detrimental effect. There is no technology still available on management of red rust thrips except some conventional spraying methods with insecticides and microbial agents. But such methods are late to keep the cosmetic value of fruits as such till maturity. Therefore, bud injection technique was tested over other bio-rational pesticide for the management of banana red rust thrips, C. signipennis.

\section{MATERIALS AND METHODS}

The investigation were carried out with nine treatments designed in randomized block design replicated three times to compare the bud inject technique for the management of rust thrips, $C$. signipennis with conventional method of spraying and bunch sleeving. The trial was framed at research farm of F. R. S., N. A. U., Gandevi for three consecutive years of 2012-13, 2013-14 and 2014-15 under ICAR-AICRP (Fruits) programme. The bud injection technique by using imidacloprid $17.8 \mathrm{SL}(0.3 \mathrm{ml} / 500 \mathrm{ml}$ water$) @ 1 \mathrm{ml} / \mathrm{bud}$ and azadirachtin (1\%) (5 ml/1 water)@ 2 ml/bud were compared with bunch sleeving at shooting stage (100 gauge thickness, $6 \%$ ventilation) and conventional spraying of different botanicals like azadirachtin (1\%) (a) $5 \mathrm{ml} / \mathrm{l}$, Neem seed kernels extract $(5 \%)$, neem oil (1\%)@2 ml/1, pongamia oil (1\%) and chlorpyriphos 20 EC (0.05\%)@ $2.5 \mathrm{ml} / 1$ as standard check and

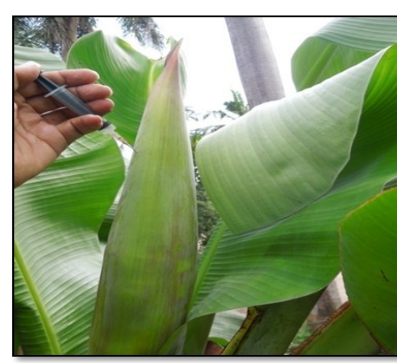

Fig. 1. Bud injection method in banana flower.

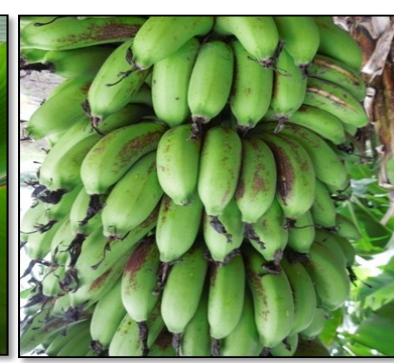

Fig. 2. Banana fruit bunch infested with red rust thrips, C. signipennis. control. Grand Naine, as commercial variety of Gujarat were selected for cultivation under research programme.

The first spray of conventional pesticide viz., azadirachtin (1\%); Neem seed kernels extract (5\%); neem oil (1\%); pongamia oil $(1 \%)$ and chlorpyriphos 20 EC was applied at the time of shooting stage of banana and the second spray after opening of all hands. The bud injection with azadirachtin (1\%) and imidacloprid 17.8 SL was given at the emergence of flower when upright position at $30^{\circ}$ angle leaving one fourth length of bud from top. Bunch sleeving was done at shooting stage with 100 gauge thickness polythene containing $6 \%$ ventilation by making holes. Observation on total fruits and infested fruits were counted to record per cent fruit infestation due to rust thrips. Similarly, bunch weight and yield of unblemished fruits were recorded. All the necessary recommended crop protection practices for other pests were followed during banana cropping period.

In anxiety to residue of imidacloprid 17.8 SL in fruit at harvest, the fruit sample were tested at Food Quality Testing Laboratory, NAU, Navsari (Gujarat) and ICAR-National Research Centre for Grapes, Pune (Maharashtra) after harvesting of bunch.

\section{RESULTS AND DISCUSSION}

Generally, rust thrips, C. signipennis fruit infestation occurs at any phase of fruit development, but damage symptoms appears at fruit bunch maturity and cause most severe damage. Both the adult and the nymph of thrips feed by puncturing plant surface cells and sucking the sap caused reddish brown oval stains/red spot on the finger, which can extent the entire length of fruit and sometime, peel cracking observed during severe invasion. When fruits infested with rust thrips, the market value is reduced although the quality of fruits is not affected and still such fruits remain edible. The peak damage symptoms of red rust thrips appeared June onwards and remains till October on fruiting stage with their higher fruit injury during September (Anonymous, 2015). The succession of red rust thrips showed that the feeding damage occurs on to young fingers soon after the flower petals dry with typical water soaked appearance on mature fruits at early phase. The rusty-red patches appear on infested fruits and later there is apparent cracking of the skin or sometimes splitting of the fruit under heavy injury. The fruits scratch is usually seen on the side of fingers that are touching or are close together, but in case of severe infestation the whole fruits may be blemished and cover more of the fruit surface (Fig. 2).

The three years mean data on bio-efficacy of biorational pesticides (Table 1) for rust thrips management revealed that bud injection with imidacloprid $(0.3$ $\mathrm{ml} / 500 \mathrm{ml}$ water)@1 ml/bud exhibited lowest fruit damage $(8.37 \%)$ at harvest and reported comparable 
K. D. Bisane et al. / J. Appl. \& Nat. Sci. 9 (1): 181 - 185 (2017)

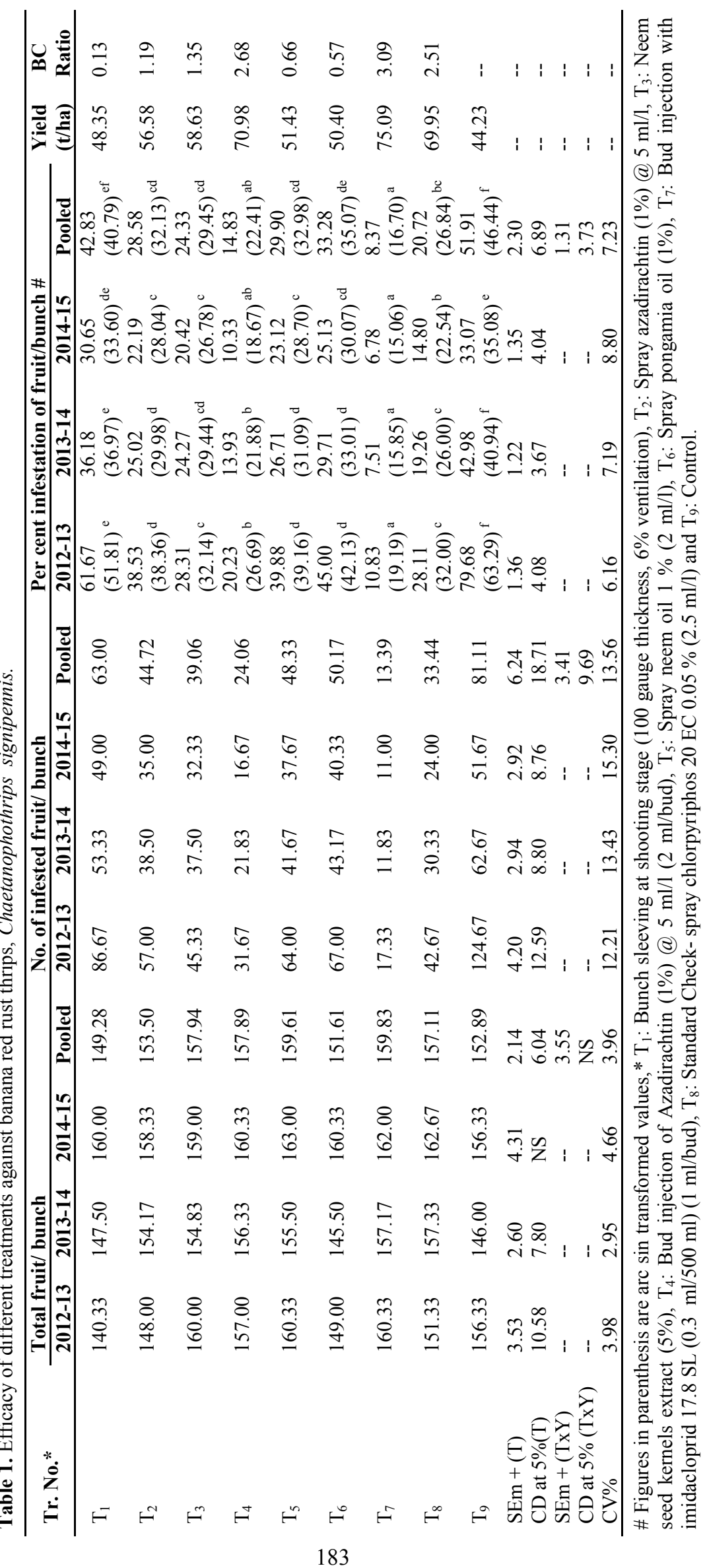


findings $(14.83 \%)$ with bud injection of azadirachtin (5ml/1)@2 ml/bud. The standard check, chlorpyriphos $0.05 \%$ also effective exhibited lesser unblemished fruits $(20.72 \%)$ and infestation level was at par to bud injection with azadirachtin (1\%). The higher thrips infestation was observed in bunch sleeving (42.83\%) and control (51.91\%). However, during individual year of 2012-13 and 2013-14, bud injection of imidacloprid was significantly superior in producing less blemished fruits over bud injection of azadirachtin and conventional spraying of chlorpyriphos. While during 2014-15, results under bud injection with imidacloprid was comparable with bud injection of azadirachtin, which was also similar to conventional spraying of chlorpyriphos.

Generally, red rust thrips flourish inside the flower bud and succeeds towards fruits for feeding during development span, which is disturbed and prohibited by bud injection technique. This method also breaks down the life cycle phase of pest and offer preventive control against rust thrips infestation. The trend of bio-efficacy dominance was almost same during all the three consecutive years of investigation period. Likewise, the thrips population was found fluctuating among the years, which was showed by decline trend of fruit infestation in successive years. The present findings are strongly supported by earlier results of least fruit damage $(<15 \%)$ due to bud injection technique with same dose of imidacloprid and azadirachtin tested at Jalgaon (Maharashtra) (Anonymous, 2013 and 2014). In another report, two spraying of biopesticides like Beauveria bassiana@3g/1 andVerticillium lecanii@3g/1 at flag leaf stage and 7 days after opening of all hands showed the control of rust thrips infestation between $11-12 \%$ in banana as compare to plant oils at Jalgaon location (Patil et al., 2015). But, biopesticide need encouraging ecological condition for their effective growth and development.

The bunch yield weight estimated on unblemished fruits was highest $(75.09 \mathrm{t} / \mathrm{ha})$ in the treatment of bud injection of imidacloprid and showed comparable findings with bud injection of azadirachtin (70.98 t/ha). Standard check chlorpyriphos $0.05 \%$ also found better as compared to other treatments recorded $69.95 \mathrm{t} / \mathrm{ha}$ yield and showed comparable results with bud injection of imidacloprid and azadirachtin. The cost of plant protection was less due to very low dose of pesticide in bud injection of imidacloprid $(0.3 \mathrm{ml} / 500 \mathrm{ml}$ water $)$ (a)1 $\mathrm{ml} / \mathrm{bud}$ and azadirachtin (5ml/1)@2 ml/bud, which exhibited the higher BC ratio of 3.09 and 2.68, respectively (Table 1). In previous findings, bud injection technique with imidacloprid had got higher $\mathrm{BC}$ ratio (3.03) at Jalgaon (Maharashtra) (Anonymous, 2013 and 2014).

The bud injection with imidacloprid $(0.3 \mathrm{ml} / 500 \mathrm{ml}$ water)@1 ml solution/bud or azadirachtin $(5 \mathrm{ml} / 1$ water)@2 ml/bud at the emergence of banana flower was effective and economical method to reduce the damage of rust thrips and improve cosmetic vaule of martetable fruits over conventional spraying during shooting stage. Low dose of imidacloprid and azadirachtin required in bud injection technology, which lower down the expenditure against conventional spraying. Besides, insecticides residue was not detected in harvested fruits as per residue report received from Food Quality Testing Laboratory, NAU, Navsari and ICAR-NRCG, Pune. The technology is new and there are no literatures existing regarding evaluation of bud injection technique in banana against red rust thrips, $C$. signipenni. Addition to this, crop rotation can be one of better cultivation practices to reduce the infestation of rust thrips by breaking life cycle succeed through pupal stage in soil.

\section{Conclusion}

On considering above all facts and nonexistence of other anticipatory technology, bud injection with imidacloprid and azadirachtin is safer and competent preventive technique for the reducing the percentage of blemished fruits $(<10 \%)$ caused due to rust thrips. The technology required very less quantity of pesticides and keeps the original superficial fruit peel appearance and significance, which in turn fetch better price on quality fruits in market and provide financial profit to banana growers and traders.

\section{ACKNOWLEDGEMENTS}

The authors are thankful to The Director of Research, Navsari Agricultural University, Navsari for providing all the necessary facilities as well as The PC (Fruits), ICAR-AICRP, IIHR, Bengaluru for providing funds during the study period. We are also grateful to The Director, ICAR-National Research Centre for Grapes, Pune and Head, Food Quality Testing Laboratory, NAU, Navsari for helping in residue analysis.

\section{REFERENCES}

Anonymous (2011). Biennial Research Report 2011. All India Coordinated Research Project on Tropical Fruits (Edi: Sidhu, A. S., Patil, P., Reddy, P.V.R., Satisha, G. C. and Sakthivel, T.). ICAR-IIHR, Bengaluru. pp 231318.

Anonymous (2012). Annual Report 2014-15. All India Coordinated Research Project on Fruits. Fruit Research Station, NAU, Gandevi. pp 1-4.

Anonymous (2013). Research Report 2013. All India Coordinated Research Project on Tropical Fruits. (Edi: Sindhu, A. S., Patil, P. and Mrs. Thomas). ICAR-IIHR, Bengaluru. pp 185-213.

Anonymous (2014). Research Report 2014. All India Coordinated Research Project on Fruits. (Edi: Patil, P., Mrs. Thomas, R. R., Shivashankara, K. S., Reddy, P.V.R. and Sakthivel, T.). ICAR-IIHR, Bengaluru. pp 273-280.

Anonymous (2015). Annual Report 2014-15. All India Coordinated Research Project on Fruits. Fruit Research Station, NAU, Gandevi. pp 5-7. 
Denmark, H. A. and Osborne, L. S. (1985). Chaetanophothrips signipennis (Bagnall) in Florida. Entomology Circular No. 274, September, 1985. Florida Dept. Agric. And Consumer Serv., Division of Plant Industry.

Hara, A. H., Jacobsen, C. and Niino-DuPonte, R. $\left(2002^{\mathrm{a}}\right)$. Anthurium thrips damage to ornamentals in Hawaii. University of Hawaii at Manoa, College of Tropical Agriculture and Human Resources, publication IP-9.pp 4.

Hara, A. H., Ronald, F. L. M., Christopher, J. and NiinoDUponte, R. $\left(2002^{b}\right)$. Banana rust thrips damage to banana and ornamentals in Hawaii. Bull. In Cooperative Extension Service, CTAHR, Hawaii. pp 1-4.

Padmanaban, B. and Mustaff, M. M. (2010). Integrated Pest Management of banana and Plaintain. Tech. Bull. No. 09. Pub.: ICAR-National Research Centre for Banana,
Tiruchirapalli (T. N.). pp 8-9.

Patil, N.M., Shaikh, N.B. and Pawar, R.D. (2015). Management of red rust thrips (Chaetanophothrips signipennis Bagnall) on banana by using biopestcides. Bioinfolet, 12(4B): 1004-1005

Sakimura, K. (1975). Danothrips trifasciatus, new species, and collection notes on the Hawaiian species Danothrips (Thysanoptera: Thripidae). Proc. Hawaiian Entomol. Soc., 22: 125-132

Schotman, C.Y.L. (1989). Plant Pest of Economic Importance reported in the Region covered by the Caribbean Plant Protection Commission. Proveg (RLAC/90/03), pp 1-190

Simmonds, N.W. (1959). Bananas. Longman Publishers. Great Britain. 